\title{
Genetic transformation of coffee
}

\author{
Alessandra Ferreira Ribas ${ }^{1}$, Luiz Filipe Protasio Pereira ${ }^{2 *}$ and Luiz Gonzaga E. Vieira ${ }^{1}$ \\ ${ }^{1}$ Instituto Agronômico do Paraná - Laboratório de Biotecnologia, CP 481, 86001-970, Londrina, PR, Brazil; ${ }^{2}$ EMPRAPA - Café, Laboratório \\ de Biotecnologia, IAPAR, 86001-970, Londrina, PR, Brazil. *Corresponding author: lpereira@iapar.br
}

In the last 15 years, considerable advances were made in coffee genetic transformation. Different research groups in the world have been able to transform coffee with genes for insect resistance, decaffeinated coffee, herbicide resistance and control of fruit maturation. Although the majority of the research is still limited to laboratory and greenhouse studies, initial field tests with transformed coffee are beginning to appear in the literature. In this review we provide an update on the state of coffee genetic transformation, presenting technical aspects related to tissue culture systems, strategies for selection and transformation with particle bombardment, as well as the use of Agrobacterium tumefaciens. We also discuss the potential applications of this technology, taking into consideration the benefits, the possible environmental risks, as well as market and consumer issues.

Key words: Agrobacterium, Coffea, biolistic, genetic engineering, transgenic.

Transformação genética de café: Nos últimos 15 anos, vários avanços foram obtidos na transformação genética de café. Diferentes grupos de pesquisa no mundo obtiveram plantas de café transformadas com genes para resistência a insetos, café descafeinado, resistência a herbicidas e controle da maturação de frutos. Apesar da maioria dos trabalhos ainda estar restrito a laboratórios e casas de vegetação, os primeiros dados de café em testes de campo começaram a surgir. Nesta revisão, os principais e mais recentes trabalhos em transformação do cafeeiro são apresentados, principalmente os aspectos técnicos de cultura de tecidos, estratégias de seleção e transformação via bombardeamento de partículas e via Agrobacterium tumefaciens. As aplicações potenciais desta tecnologia considerando possíveis riscos e benefícios assim como aspectos de mercado e consumo são também discutidos.

Palavras-chave: Agrobacterium, Coffea, biobalística, engenharia genética, transgênico.

\section{INTRODUCTION}

Plant genetic transformation permits an increase in the amplitude of the gene pool generally available in conventional breeding systems, allowing gene transfer across species. It is particularly important in perennial crops and tree species in which development of new cultivars is often difficult due to their long generation time. Thus, it can be a short cut to introduce a new trait and to develop new cultivars without losing the genetic background of the original transformed cultivar. Genetic transformation has been changing plant science and agriculture around the globe. Ten years after the release of the first commercial genetically modified plant, transgenic crop production is reaching the 90 million hectare production mark (James, 2005). Besides the direct application in breeding programs for commercial purposes, plant transformation is a powerful instrument in plant science research. It can be used to knock out genes or to over-express them. This tool has been of great value and applicable in several research areas such as plant physiology, plant biochemistry and phytopathology, among others.

Conventional breeding efforts have been able to fulfill the majority of agricultural needs for coffee production, with remarkable success in selecting and producing cultivars for rust resistance, for changes in the maturation period and in plant architecture. However, the introduction of a new trait into a coffee elite variety, using conventional breeding techniques, is a lengthy process, which could take 20 to 35 years before the release of a new cultivar. The use of genetic engineering to introduce new traits into elite coffee genotypes can reduce the necessary time for obtaining new cultivars 
with desirable traits, such as disease resistance and improved quality. Furthermore, plant transformation opens a window of opportunity to introduce traits from different species, adding characteristics which would be difficult or even impossible to acquire using traditional breeding techniques, such as insect resistance, herbicide resistance, cup quality and tolerance to abiotic stress like drought or frost.

Genetically modified (GM) coffee plants have been produced by different research groups in the world (Hatanaka et al., 1999; Spiral et al., 1999; Leroy et al., 2000; Ribas et al., 2005a,b). Despite significant advances over the last 15 years, coffee transformation is still very laborious, with bottlenecks in the methodology that makes it far from a routine laboratory technique.

The objective of this review is to provide an update on coffee transformation, bringing together the relevant scientific information and discussing the technical constraints. The potential use of coffee transformation, its perspectives and the potential benefits and risks are addressed, as well as considerations on market and consumer acceptance of genetically modified coffee products.

\section{Technical Issues in Coffee Transformation}

As for any other work involving plant genetic engineering, an efficient tissue culture protocol, a reliable selective system and the transformation method are critical parameters in coffee transformation. The combinations of these parameters, i.e., the timing of initiating the selection process according to the transformation system used, are also important issues to be considered and are presented below.

\section{Tissue Culture}

The ideal tissue culture system for use in a plant transformation protocol should provide the efficient regeneration of the cultivars or species. Unfortunately, plant regeneration in coffee is strictly dependent on the germoplasm. Of the two most economically important coffee species, $C$. canephora shows a faster and easier response for tissue culture work than $C$. arabica. However, both species have a remarkable variability for tissue culture response among different cultivars from the same species. In a study involving C. arabica, the capacity of embryogenic regeneration was evaluated in 15 breeding lines (Molina et al., 2002). Leaf explants were collected from $\mathrm{F}_{3}, \mathrm{~F}_{4}$ and $\mathrm{F}_{5}$ plants of the cross between Coffea arabica cv. Caturra and the Timor Hybrid throughout the year over 3 years to ascertain the effect of the collection period. It was verified that embryogenic capacity in coffee depends on the genotype and this character is fixed in the early generations $\mathrm{F}_{3}$ or $\mathrm{F}_{4}$. No relation was found between embryogenic response in the months evaluated and climatic elements such as: precipitation, temperature, relative humidity and solar brightness. However, the observed differences in the embryogenic responses of the genotypes also depended on the time of the year in which the leaf explants were taken and on the growing conditions of the donor plants. Berthouly and Michaux-Ferrière (1996) also demonstrated the variability of embryogenesis response among genotypes of $C$. canephora.

Several techniques, such as somatic embryogenesis, meristem and axillary bud culture, induction of adventitious buds, androgenesis and protoplast culture, have been reported for plant regeneration and propagation using different types of tissue and coffee species (reviewed by Carneiro, 1997). Embryogenic tissues or somatic embryos have been the target tissues for most of the work in coffee transformation (table 1). In fact, after overcoming the initial barriers to produce embryogenic tissue and somatic embryos, these tissues have a remarkable capacity for production of secondary embryos, which makes them an ideal source of explant for transformation and micropopagation. Torpedoshaped embryos have been considered the best tissue for coffee transformation due to their high potential for secondary somatic embryogenesis, favoring the regeneration of transgenic plants (Spiral et al., 1993; Leroy et al., 2000).

Hatanaka et al. (1999) used two tissue culture systems for regenerating transgenic plants: indirect somatic embryogenesis for $C$. arabica using a modified half-strength MS medium (Murashige \& Skoog, 1962) containing a combination of $1 \mu \mathrm{M} N-(2-c h l o r o-4$ pyridyl)- N'- phenylurea (4-CPPU) and $5 \mu \mathrm{M} 2,4 \mathrm{D}$, and a direct method for both $C$. arabica and $C$. canephora in a half-strength MS plus $20 \mu \mathrm{M} 2 \mathrm{iP}$ with fresh medium subcultures made at 3-week intervals.

As an alternative method, Mishra and Sreenath (2004) used hypocotyl explants for transformation. The hypocotyl segments were co-cultivated with Agrobacterium before the production of embryogenic tissue also using half-strength MS medium plus IAA, KIN and the appropriated selective agent.

\section{Selective agent}

Another requirement for successful recovery of transgenic plants is the choice of a suitable selective agent, its optimal concentration and the timing of selection. During 
transformation, the selective agents must allow the proliferation of the transformed cells without the toxicity effects of polyphenolic oxidation from surrounding stressed or dying tissues. Thus, timing, concentration and the type of the selective agent, with special consideration of their activity and translocation in the tissue, are factors that should be considered for a successful transformation protocol. Van Boxtel et al. (1997) assayed five selective agents (chlorsulfuron, glufosinate, glyphosate, hygromycin and kanamycin) for coffee transformation. In embryogenic cells and suspensions only kanamycin at a concentration of $100 \mathrm{mg} . \mathrm{L}^{-1}$ for $C$. canephora and glufosinate at $3 \mathrm{mg} . \mathrm{L}^{-1}$ for both $C$. canephora and Congusta were capable of inhibiting growth of embryogenic suspensions. Glyphosate at concentrations up to $90 \mathrm{mg}$. $\mathrm{L}^{-1}$ was not sufficient for inhibiting growth and both chlorsulfuron and hygromycin provoked severe necrosis in callus. The authors concluded that ammonium glufosinate showed the most effective inhibition of callus formation with leaves of $C$. arabica, Arabusta and C. canephora without causing early tissue necrosis. The sensitivity to selective agents was also genotype dependent. The clone 197 of C. canephora was the most sensitive to all selective agents and Arabusta was

Table 1. Summary of Coffee sp transformation studies.*

\begin{tabular}{|c|c|c|c|c|}
\hline Coffea species & Explant used & Transformation method & Results & Reference \\
\hline \multirow[t]{13}{*}{ C. arabica } & Protoplast & A. tumefaciens & Transient GUS expression & Spiral and Pétiard (1991) \\
\hline & Somatic embryos, cotyledons & A. tumefaciens & $\begin{array}{l}\text { Kanamycin integration, no } \\
\text { regeneration }\end{array}$ & Feng et al. (1992) \\
\hline & Protoplasts & Eletroporation & $\begin{array}{l}\text { Kanamycin integration, no } \\
\text { regeneration }\end{array}$ & Barton et al. (1991) \\
\hline & $\begin{array}{l}\text { Somatic embryos - arabica } \\
\text { and arabusta }\end{array}$ & A. rhizogenes & GUS integration, plant regeneration & Spiral and Pétiard (1993) \\
\hline & Somatic embryos & $\begin{array}{l}\text { A.rhizogenes, } \\
\text { A. tumefaciens }\end{array}$ & $\begin{array}{l}\text { Putative transformed callus, T-DNA } \\
\text { amplification }\end{array}$ & Freire et al. (1994) \\
\hline & Somatic embryos, leaves & Biolistic, plasmidial DNA & Transient $G U S$ expression & Van Boxtel et al. (1995) \\
\hline & Cotyledons, leaves & A. rhizogenes & Hairy-root plant regeneration & Sugiyama et al. (1995) \\
\hline & Somatic embryos & A. tumefaciens & $\begin{array}{l}\text { Cry } 1 \mathrm{Ac}, \text { csr1-1 integration, plant } \\
\text { regeneration }\end{array}$ & Leroy et al. (2000) \\
\hline & Leaves, embryogenic tissue & Biolistic delivery & GUS expression & Rosillo et al. (2003) \\
\hline & $\begin{array}{l}\text { Embryogenic tissue, somatic } \\
\text { embryo }\end{array}$ & Electroporation & $\begin{array}{l}G U S \text { expression, secondary embryo } \\
\text { formation }\end{array}$ & Da Silva \& Yuffá, (2003) \\
\hline & $\begin{array}{l}\text { Embryogenic tissue, somatic } \\
\text { embryos }\end{array}$ & A. tumefaciens & $\begin{array}{l}\text { GFP expression, CaMxMT1 } \\
\text { integration, transformed embryogenic } \\
\text { tissue plant }\end{array}$ & Ogita et al. (2004) \\
\hline & Embryogenic tissue & Biolistic delivery & $\begin{array}{l}G U S \text { and } B A R \text { gene integration, plant } \\
\text { regeneration }\end{array}$ & Cunha et al., (2004) \\
\hline & Embryogenic tissue & A. tumefaciens & $\begin{array}{l}\text { Antisense } \mathrm{ACC} \text { and } B A R \text { gene } \\
\text { integration, plant regeneration }\end{array}$ & Ribas et al. (2006) \\
\hline \multirow[t]{11}{*}{ C. canephora } & Somatic embryos & A. rhizogenes & GUS integration, plant regeneration & Spiral et al. (1993) \\
\hline & Somatic embryos & A. rhizogenes & $G U S$ integration, plant regeneration & Spiral and Pétiard (1993) \\
\hline & Somatic embryos & A. tumefaciens & Bt. integration, plant regeneration & Leroy et al. (1997) \\
\hline & Embryogenic tissue & A. tumefaciens & $\begin{array}{l}G U S \text { and HPT integration, plant } \\
\text { regeneration }\end{array}$ & Hatanaka et al. (1999) \\
\hline & Somatic embryos & A. tumefaciens & $\begin{array}{l}\text { Cry } 1 \text { Ac, csr1-1 integration, plant } \\
\text { regeneration, field tests }\end{array}$ & $\begin{array}{l}\text { Leroy et al. (2000), Perthuis } \\
\text { et al. (2005) }\end{array}$ \\
\hline & $\begin{array}{l}\text { Embryogenic tissue, somatic } \\
\text { embryos }\end{array}$ & A. tumefaciens & $\begin{array}{l}\text { GFP expression, CaMxMT1 } \\
\text { integration, } \\
\text { plant regeneration }\end{array}$ & Ogita et al. (2004) \\
\hline & Embryogenic tissue & A. tumefaciens & $G U S$ and $B A R$ gene integration & Cruz et al., 2004 \\
\hline & Hypocotyl & A. tumefaciens & $\begin{array}{l}G U S \text { and HPT integration, plant } \\
\text { regeneration }\end{array}$ & Mishra and Sreenath (2004) \\
\hline & Embryogenic tissue & Biolistic delivery & $\begin{array}{l}G U S \text { and } B A R \text { gene integration, plant } \\
\text { regeneration }\end{array}$ & Ribas et al., (2001, 2005a) \\
\hline & Embryogenic tissue & A. tumefaciens & $\begin{array}{l}G U S \text { and } B A R \text { gene integration, plant } \\
\text { regeneration }\end{array}$ & Ribas et al., $(2003,2006)$ \\
\hline & $\begin{array}{l}\text { Leaf explants, embryogenic } \\
\text { tissue }\end{array}$ & A. tumefaciens & $\begin{array}{l}D S R F P \text { and NPTII gene integration, } \\
\text { plant regeneration }\end{array}$ & Canche-Moo et al., (2006) \\
\hline
\end{tabular}

* Updated from Spiral et al. (1999). 
the most vigorous being moderately inhibited by the action of the chemicals.

The first transformed coffee plants used NPTII genes and kanamycin as selective agent (Spiral et al., 1993), but difficulties of screening transformation events in $C$. canephora with this antibiotic were reported. Hygromycin is another antibiotic successfully used as a selective agent (Hatanaka et al., 1999; Ogita et al., 2004; Mishra and Sreenath, 2004). A double selection approach was used by Hatanaka et al. (1999), where putative transgenic calli were initially selected under an increasing hygromycin concentration and the small plantlets were finally selected in a medium containing kanamycin.

Since there are market and consumer issues concerning the use of antibiotic resistant markers on transformed plants, the use of herbicide resistant genes or positive selection marker genes is recommended, where commercial use of the transgenic plant is sought. The herbicide chlorsulfuron has been successful used as selective agent on embryogenic tissue transformed with a csrl-1 gene (Leroy et al., 2000). Ribas et al. $(2005 \mathrm{a}, \mathrm{b})$ used glufosinate as selective agent to produce transformed $C$. canephora with the $B A R$ gene. Glufosinate was very effective to select transformed tissue, using either particle bombardment or Agrobacterium tumefaciens as the transformation system.

Positive selection systems are an alternative to the use of antibiotics for selection (Penna et al., 2002). Samson et al. (2004) evaluated the response of somatic embryos to formation using mannose and xylose as a positive selection in a glucose-free medium. Testing four species of Coffea, they demonstrated that the explants were able to grow in the presence of mannose as carbohydrate source, but not in different concentrations of xylose. This indicates the potential use of xylose isomerase genes as a positive selection marker in coffee transformation.

\section{Transformation system}

Despite the complexities to achieve a reliable tissue culture and selective system for transformation, few research groups have been able to transform Coffea using Agrobacterium, biolistic or electroporation methods. Fullgrown plants were only obtained using the two first methods, for both C. canephora and C. arabica.

Electroporation: Transformed somatic embryos of $C$. arabica were first reported by Barton et al. (1991) using electroporation to integrate foreign DNA in the protoplast.
Regeneration of transformed embryos and plantlets resistant to kanamycin were obtained but the plantlets did not survive due their feeble root system.

The conditions for the transformation of coffee somatic embryos by electroporation were evaluated by transient expression of the $\beta$-glucuronidase gene (GUS) (Da Silva \& Menéndez-Yuffá, 2003). Optimal conditions were determined for use prior to electroporation of the torpedo-shaped somatic embryos with the pCambia 3201 plasmid. The best results were achieved when the embryos were pretreated for one hour in an enzymatic solution ( $2 \%$ cellulase and $1 \%$ macerozyme in $5 \mathrm{mM}$ MES, 0.5 M mannitol and $25 \mathrm{mM} \mathrm{CaCl}_{2}$ at pH5.8), incubated in potassium aspartate buffer $\mathrm{pH} 5.8(70 \mathrm{mM}$ aspartic acid, $5 \mathrm{mM}$ calcium gluconate, $5 \mathrm{mM}$ MES and 0.4 $\mathrm{mM}$ mannitol) at $28^{\circ} \mathrm{C}$ for three hours with changes every hour, and finally electroporated at $900 \mu \mathrm{F}, 375 \mathrm{~V} / \mathrm{cm}$. The electroporated tissues were then cultured in liquid medium containing $1 / 2$ strength MS salts, $100 \mathrm{mg} . \mathrm{L}^{-1}$ myo-inositol, 35 mg.L. $\mathrm{L}^{-1}$ cysteine, $10 \mathrm{mg} . \mathrm{L}^{-1}$ thiamine, $30 \mathrm{~g} . \mathrm{L}^{-1}$ sucrose and 8 mg. $\mathrm{L}^{-1}$ benzyladenine in order to induce secondary somatic embryogenesis. They obtained regenerated plantlets showing GUS expression and confirmed the presence of GUS and $B A R$ genes in two out of eight regenerated plantlets (Da Silva \& Menéndez-Yuffá, 2003).

Biolistic delivery: Direct gene transfer via particle bombardment offers some advantages in relation to transformation using Agrobacterium, mainly in the use of simple vector constructions and less demanding transformation protocols, since the complex plant/bacterium interrelationship is eliminated (Gray and Finer 1993).

Van Boxtel et al. (1995) were the first to describe the transient expression of the GUS marker gene following biolistic delivery of foreign DNA into coffee tissues. Testing several kinds of explants, including callus, suspension cultures, somatic embryos and leaves, they also observed light bluish staining after X-gluc incubation in control treatments, indicative of endogenous GUS expression. The effect of antioxidants to suppress tissue browning during $\mathrm{X}$ gluc incubation was also tested but none of these (caffeine, PVP-10 or sodium metabisulfite) had a positive effect on preventing oxidative browning and GUS-staining intensity. They concluded that suspension cultures and somatic embryos were less appropriate for transient expression studies because these tissues are more difficult to handle during the bombardment phase and also because endogenous blue staining was observed for both somatic embryos and 
controls. Leaves from in vitro microcuttings showed the highest levels of transient expression, which might be related to the juvenile character of this tissue compared to leaves of greenhouse-grown plants that present a higher tendency for necrosis. The best results were obtained using the EF1 $\alpha-\mathrm{A} 1$ promoter from Arabidopsis thaliana which increased GUS expression in coffee leaves by 2 to 5 fold in comparison to the CaMV35S promoter.

Rosillo et al. (2003) evaluated interactions between osmotic pre-conditioning of cells and physical parameters for bombardment of C. arabica var. Colombia line BK620. Using the vector pCambia2301, the highest transient GUS expression was obtained using either 900 psi with $9 \mathrm{~cm}$ or 1550 psi with $12 \mathrm{~cm}$ as target distance. Four hours of treatment of the cells with mannitol and sorbitol prior to bombardment increased up to ten-fold the number of cells showing GUS transient expression.

The first report of successful regeneration of transgenic coffee plants (C. canephora) using the biolistic transformation system was recently published by Ribas et al. (2001, 2005a). Using the pCambia3301 plasmid containing GUS report gene and $B A R$ gene that confer resistance to ammonium glufosinate as selectable marker, they demonstrated that the $B A R$ gene was suitable for selecting transformed tissue in vitro and herbicide screening can be applied for in vivo identification of transgenic coffee plants. Cunha et al. (2004) described a methodology for transformation of C. arabica using biolistics, where embyogenic callus was transformed with nptII and GUS genes. The regenerated plants showed expression of the GUS gene whose presence was also detected by PCR.

Gene transfer by Agrobacterium tumefaciens has become the most frequently used method for transferring foreign genes into plant cells (De La Riva et al., 1998). The natural Agrobacterium preference for interaction with dicotyledonous plants together with the amount and diversity of phenolic compounds in coffee are certainly important factors for this method of transformation being the most frequently reported in Coffea. Transformed tissues have been obtained with both $A$. rhyzogenesis and A. tumefaciens, but only the later has consistently led to regeneration of transformed plants. Different strains of A. tumefaciens have been used, namely LBA4404, C58, EHA101 and 105, all of them successful in transforming coffee tissues.

Ocampo and Manzanera (1991) were the first to demonstrate that $C$. arabica tissues could be infected by wild strains of $A$. tumefaciens. They used different kinds of tissues for transformation and although they were capable of infecting hypocotyls of in vitro germinated coffee seeds, no regenerated plants were reported.

Another initial report on genetic transformation of coffee involved the co-cultivation of protoplasts with different strains of Agrobacterium tumefaciens carrying NPTII and $\beta$ glucoronidase markers (Spiral and Pètiard, 1991). Transient expression was demonstrated by a GUS histochemical assay on callus derived form treated protoplasts but plant regeneration was again not obtained. Following this work, Spiral et al. (1993) used $A$. rhizogenes with a binary plasmid p35S-GUS-INT carrying GUS and NPTII genes to transform torpedo-shaped somatic embryos of $C$. canephora that were scapel wounded before inoculation. They regenerated plantlets that after assay for GUS activity showed the presence of the transformed genes by PCR analysis. At the time of these experiments, they had no reliable selective system for transformation, thus the $A$. rhizogenes vector was used for the phenotypic detection of the transformed tissue based on the production of hairy roots (Spiral et al., 1999). Coffee transformation with $A$. rhizogenes was very efficient and led to the regeneration of transgenic plants without using antibiotic or herbicide selection. However, some transformed plants of C. canephora showed some undesirable phenotypes such as short internodes and crinkled leaves, while $C$ arabica exhibited a more conventional phenotype, but still had short internodes and a specific shape expressed as an erect form.

Leroy et al. $(1997,2000)$ transformed somatic embryos of $C$. canephora and $C$. arabica with $A$. rhizogenes $\mathrm{A}_{4}$ and/ or $A$. tumefaciens LBA4404. The T-DNA region contained the CRY1Ac gene from Bacillus thuringiensis designed for providing insect resistance, plus the CSR 1-1 gene that confers resistance to the herbicide chlorsulfuron herbicide and the GUS reporter gene. They demonstrated that 30 to $80 \%$ of calli that developed in selective medium showed a deep blue color characteristic of GUS-transformed tissue. Molecular assays confirmed the presence of these genes in the plant genome. Coffee plants transformed with disarmed A. tumefaciens showed normal phenotype while plants transformed with armed $A$. rhizogenes showed a modified phenotype named "hairy root' that was not agronomically desirable. The plants were tested both in the greenhouse and in the field for resistance to leaf miner, as reviewed below.

Hatanaka et al. (1999) transformed C. canephora embryogenic calli by co-cultivating with $A$. tumefaciens EHA101 carrying the plasmid pIG121-Hm containing GUS, hygromycin phosphotransferase (HPT) and neomycin 
phosphotransferase II (NPTII) genes in the T-DNA region. The genes GUS and HPT were detected by PCR in transgenic plants. Ogita et al. (2004) also used the strain EHA101 but with the pBIH1-IG modified vector which contained a GFP gene. Expression of GPF could be detected in regenerated somatic embryos and also in whole regenerated plants.

The methodology for genetic transformation of Coffea using Agrobacterium was described in detail by Leroy and Dufour (2004). They were able to transform 20 different genotypes of either $C$. arabica or $C$. canephora by cocultivation of embryogenic calli with A. tumefaciens. Two genes were transferred to the coffee plants, CSRl-1 which codes for tolerance to the herbicide chlorsulforon, and the CRY1-AC gene, a Bacillus thurigiensis gene which codes for resistance to coffee leaf miner. Using a similar methodology, Ribas et al. (2005b) were able to transform C. canephora plants using $A$. tumefaciens EHA105 with the BAR gene producing plants tolerant to the herbicide ammonium glufosinate.

The Agrobacterium transformation conditions such as concentration of bacterium suspension and the time used for co-cultivation were variable. The most frequent concentration of Agrobacterium $\left(\mathrm{OD}_{600 \mathrm{~nm}}\right.$ ) used was around 0.5 (Leroy \& Dufour, 2004) ranging from 0.2 (Ribas et al., 2005b) to 0.6 (Hatanaka et al., 1999). The time of co-cultivation varies from $10 \mathrm{~min}$ (Ogita et al., 2004) to four days (Mishra and Sreenath, 2004). Other practices have also been used to improve Agrobacterium infection, such as incubation in the dark, use of acetosyringone during co-cultivation, sonication (Ribas et al., 2005b), wounding of explants prior to co-cultivation (Leroy et al., 2000) and vacuum infiltration (Chance-Moo et al., 2006).

\section{Applications}

Insect resistance: Production of coffee plants resistant to insects has been a long sought objective of many breeding programs. The insects responsible for the main problems affecting coffee production are coffee berry borer $(\mathrm{CBB}$, Hypothenemus hampei) and leaf miner (Perileucoptera coffeella). The potential use of genes from Bacillus thuringiensis $(\mathrm{Bt})$ to protect against leaf miner has been demonstrated by Guerreiro Filho et al. (1998) through the selection of three proteins, CryIA(c), CryIB and CryIE, with toxicity towards Perileucoptera sp.

Coffee transgenic plants carrying a synthetic version of the cry1Ac gene have been produced (Leroy et al. 2000). Transformed plants highly resistant to leaf miner under greenhouse conditions were tested under field conditions in French Guyana during 4 years for field resistance (Perthuis et al., 2005) in an experiment with 54 different transformation events. Approximately $70 \%$ of the events tested were resistant to leaf miner. They also observed that the transformed plants presented similar growth and development compared to control plants. It was the first time that an important agronomic trait was introduced into a coffee plant and also field tested. Unfortunately, the field trial was vandalized and the experiment had to be suspended (Montagnon, 2005).

Since there are $\mathrm{Bt}$ proteins toxic for coleopterans, we can assume that it will be possible to use them against CBB. Mendez-Lopez et al. (2003) demonstrated that the Bt serovar israelensis was highly toxic to $\mathrm{CBB}$ during the first-instar of the larvae. Protection against coleopteran has been obtained in corn using the $\mathrm{Bt}$ gene $C R Y 3 B b 1$, indicating that this or a similar Bt gene might be effective against the CBB. This is an important example of the potential utilization of the transformation technology, since to date, there is no reported source of resistance to $\mathrm{CBB}$ in Coffea species and the chemical control of the insect is difficult due the its life cycle, spent most of the time inside the berry. In another approach to control $\mathrm{CBB}$, an $\alpha$-amylase inhibitor from Phaseolus vulgaris has been considered as a target gene for introduction in coffee plants. In vitro assays demonstrated that this protein can inhibit CBB growth and development (Grossi de Sá et al., 2004). Coffea arabica plants have been transformed with this gene, but the transformed plants have still not been tested (Barros, personal communication).

Control of $\mathrm{CBB}$ using transformed plants could represent an additional health benefit. In Bt corn, a decrease in both Fusarium and the mycotoxin fumosin has been reported (Munkvold et al., 1999). Since H. hampei acts as a vector for fungi penetration in coffee (Vega and Mercadier, 1999), lesser CBB infestation could reduce the amount of Aspergillus flavus and A. ocraceous, and consequently the amount of ochratoxin produced in the coffee, which is of major concern in the most important coffee markets, Europe and U.S.A.

However, the cultivation of coffee with resistant insect transgenes has to be accompanied by intense pest management studies. The constant selective pressure of the plants on the insect population will probably favor the emergence of insect resistant populations. Since coffee plantations can remain productive for as long as 30 years without renovation of the trees, strategies for pest management must be implemented together with the introduction of insect resistant transgenic 
coffee plants, such as the use of cultivated lines of nontransgenic coffee, biological control with natural predators, and other agronomic practices to keep resistant insect populations under control.

Caffeine content: Low caffeine and decaffeinated coffee represent around $10 \%$ of the coffee sales around the world. The industrial process for coffee decaffeination can be expensive and also affects the original flavour of coffee (Heilmann, 2001; Davis, 2002).

The main pathway for biosynthesis of caffeine in coffee fruits and leaves has been elucidated (Suzuki and Waller, 1984) and the main N-methyl transferases genes involved in caffeine synthesis have been identified (Ogawa et al., 2001; Uefuji et al., 2003a). Genes responsible for successively adding methyl groups to xanthosine converting it to caffeine were patented for use as antisense suppressors of caffeine synthesis (Stiles et al., 2000; Mizuno et al., 2003; Uefuji et al., 2003b).

Ogita et al. $(2003,2004)$ obtained transgenic coffee plants with suppressed caffeine synthesis using RNA interference (RNAi) technology for inhibition of a theobromine synthase gene (CaMXMT1). Two RNAi vectors were constructed with identical sequences both containing a spacer fragment derived from GUS gene. The RNAi was under the control of the CaMV35S promoter and nopaline synthase (NOS) terminator. They successful produced low-caffeine plantlets of $C$. canephora with $70 \%$ reduction of both theobromine and caffeine in the leaves compared to the control plants. Transcript down-regulation occurred not only for the CaMXMT1 gene, but also for CaMXT1, another gene involved in the methylation steps of caffeine biosynthesis. Theobromine and caffeine reduction in transformed C. arabica embryogenic tissue was also analyzed. The transgenic tissue showed a reduction of theobromine and caffeine content ranging from 65 to 85 $\%$ and from 65 to $100 \%$, respectively. They concluded that RNAi appears to confer a global effect on expression of relevant genes and that theobromine is the major intermediate in caffeine biosynthesis as its decrease was proportional to the reduction in caffeine content. Furthermore, this is the first report of the use of the RNAi technique in Coffea, a strategy that could be applied for several other genes aimed at producing new agronomic traits or simply to study biochemical pathways through the inhibition of a gene.

It is only recently that a naturally decaffeinated Arabica coffee germoplasm has been reported (Silvarolla et al. 2004). The low caffeine content is probably due a mutation in the caffeine synthase gene, responsible for the last step of the caffeine biosynthetic pathway. Molecular characterization of the gene involved in this mutation will certainly provide more insight to design strategies to inhibit caffeine production. The introduction of this characteristic into commercial cultivars using conventional breeding is currently under way.

Physiological modification of fruit ripening: Uniformity during fruit ripening is decisively related to cup quality in coffee, and consequently to the value of the product. Red and cherry fruits are the ideal ripening stage, which can produce the best organoleptical characteristic for coffee. The presence of green fruits and over-ripened fruits changes the acidity, the bitterness and consequently the cup quality.

Fruit maturation could be modified by genetic control of either the blossom period or the late stages of the maturation process. However, regulation of flowering is a complex mechanism involving the expression and interaction of several genes (Parcy 2005). A full study on the mechanisms of the genetic control of coffee blossoming has not been carried out yet. Research on genes involved in the phase change, when meristems are transformed from a vegetative stage to a reproductive stage, might provide insight into flowering control. Several of these genes, such as $L E A F Y$, APETALA and CAULIFLOWER have been reported for Arabidopsis and certainly will be found in coffee. It would also be interesting to study how these genes are activated by the spring showers during the blossoming period. The utilization of data from the Coffee Genome Project (Vieira et al. in this publication) would allow the identification of genes involved in flowering and the study of their effects on regulation of this physiological process.

Another way to improve fruit ripening uniformity is to control the action of genes involved in the last steps of the maturation process, which is triggered by ethylene. In coffee, as well as other climacteric fruits, a dramatic increase in ethylene biosynthesis promotes the subsequent steps of fruit ripening, with biochemical and physiological changes (Pereira et al., 2005). These changes include softening of the cell wall, sugar accumulation, modification of phenolic and organic acid compounds, accumulation of anthocyanins and carotenoids. The ethylene burst stimulates an increase in respiration, which will provide the necessary energy for such metabolic changes. To control coffee maturation, two of the main genes of the enzymes involved in ethylene biosynthesis have been cloned, namely ACC synthase and ACC oxidase (Neupane et al., 1999; Pereira et al., 2005). Introduction 
of the ACC oxidase gene in antisense orientation has been recently achieved in our laboratory for both $C$. arabica and C. canephora (Ribas et al., 2003, 2005b). Further work to study the effect of inhibition of these genes on fruit maturation and ethylene production in transgenic plants are currently under way.

The inhibition of genes downstream to the initial ethylene burst is also an option to control coffee fruit maturation. Gene families such as expansins, polygalacturonases, and pectin methyl esterases have been used to improve fruit maturation in different climateric fruits. Several of these genes, encountered in the Coffee Genome Project, are currently being studied with the aim of identifying those that are fruit specific and that can be used to regulate fruit maturation (Budzinski et al., 2005). Exploitation of these genes in transformation projects would also lead to a better understanding of the biochemical changes occurring during the ripening process of coffee.

Herbicide Tolerant Plants: Herbicide tolerant coffee plants can facilitate farming practices by allowing an appropriate control of weeds in coffee plantations. Weed control is highly recommended in coffee plantations, since they can causes yield losses of up to $20 \%$, mainly due nutrient and water competition (Blanco et al., 1982). Nowadays, farmers in different coffee growing regions of the world have been increasingly replacing low-density with high-density planting regimes. Tillage normally restricts high-density coffee planting, since wide plant spacing is required to enable access to the crop; this is also costly in terms of labor and may result in significant crop damage. The inclusion of herbicides in an integrated weed management program is a recommended practice for controlling weeds in high-density coffee planting systems for an economically sustainable coffee production. Furthermore, the improvement of the economic situation in coffee producing countries will certainly be followed by a reduction of manual labor available for farms, with a consequent increase in labor wages. The use of chemical applications can decrease by around ten times the hours of labor required for weed control (Carvalho, 1982). Thus, herbicide tolerant coffee plants should prove useful in diverse farming systems. Another advantage of this technology would be the reduction of phytotoxicity that occurs during traditional herbicide application. To date, herbicide tolerant germoplasm has not been identified in Coffea species, and consequently conventional plant breeding for herbicide-tolerant varieties is still not possible.
Ribas et al. (2005a, 2006) introduced the $B A R$ gene in $C$. canephora and C. arabica. The BAR gene inactivates the herbicide ammonium glufosinate, which is normally used as a non-selective pre-emergence herbicide and also for pre-harvest desiccation (Botterman and Leemans, 1988). Transgenic plants were sprayed with the herbicide ammonium glufosinate (Finale ${ }^{\circledR}$ ) under greenhouse conditions and showed no phytotoxicity symptoms (figure 1). The herbicide resistant plants were found to support up to eight times the recommended field application.

Nevertheless, the application of this technology must be accompanied by proper weed management control, since the constant application of just one herbicide will certainly promote the emergence of tolerant weed populations. The addition of two or more genes for resistance to different groups of herbicide together with appropriate weed management techniques, might help avoid this situation.

Abiotic Stress Tolerance: Improve coffee tolerance to drought, salt and frost is a main objective in several coffee breeding programs. Drought is one of the major constraints in several coffee production areas in the world. In Minas Gerais, the largest coffee region in Brazil, short drought periods can result in 20 to $30 \%$ loss in yield at harvest. Salt, and also aluminum stress, can be a limiting factor for coffee growers due their phytotoxicity and the interference with absorption of nutrients by the plant. Increased cold tolerance in coffee would certainly help avoid damage at least by slight frosts in coffee plantations in the south and southeast regions of Brazil.

With the identification of stress-inducible genes and studies on their role in stress tolerance, several approaches have been proposed to improve drought tolerance in plants. Dehydration-response transcription factors, which are involved in the response to water, cold and salt stress, have been used to produce transgenic plants with better stress tolerance (Kasuga et al., 1999). These genes are activators of several stress-related family genes such as cor $15 a$, cor6.6, rd29A, rd17, kin 1, and erd10. Initial data mining of the Coffee Genome Project Database demonstrated the presence of several abiotic stress-related genes (Vinecky al., 2005) whose expression could be manipulated to improve coffee tolerance to these factors.

One of the responses to abiotic stress is the accumulation of non-toxic, low molecular weight compounds, called compatible solutes or osmolytes, such as proline, sorbitol, mannitol and glycine betaine. Genetic engineering of coffee 


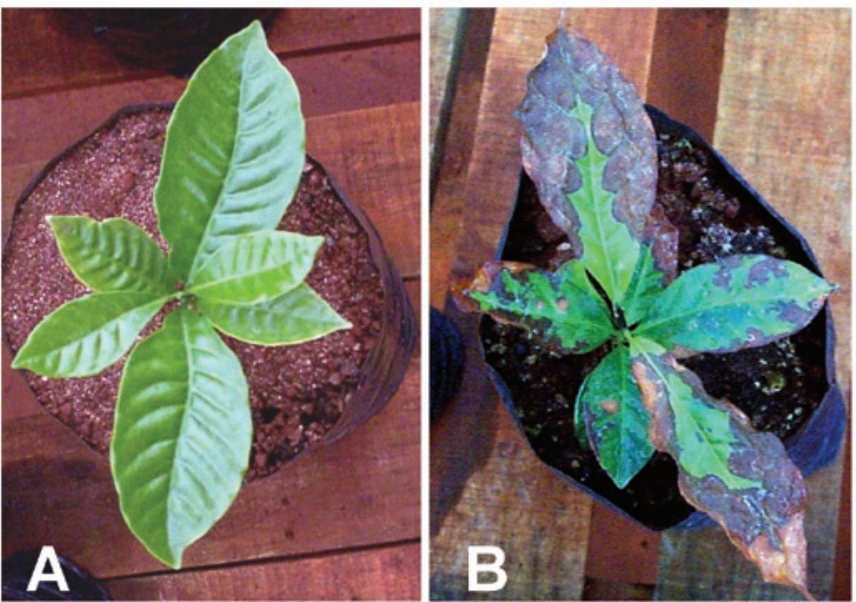

Figure 1. Herbicide tolerant coffee plant (A) and nontransformed plant (B), one week after spraying with ammonium glufosinate at $200 \mathrm{mg} . \mathrm{L}^{-1}$ (Ribas et al., 2006).

plants aimed at increasing these compounds may also improve drought tolerance. Citrus rootstocks transformed with the gene $\Delta$-pyrroline-5-carboxylate synthetase (P5CS) showed an increased proline content in the leaves coupled with tolerance to drought (Molinari et al., 2004). A similar approach is currently being used by in our laboratory where coffee plants are transformed with constitutive stressinducible promoters driving the gene P5CS.

\section{Market and Consumer Approval}

Considering that the technology for coffee transformation is available, and its use may bring benefits to all segments of the coffee industry, the main hurdle for the widespread use of this technology will be consumer approval and acceptance of genetically modified (GM) coffee. This is an important issue to be considered in terms of planning and working with GM coffee. Since the habit of drinking coffee is regarded as a pleasure in most societies, the idea of "drinking a genetically modified product" might be a limitation to certain markets. However, given that field testing of GM coffee is still at an initial stage, we could predict that the presence of GM coffee for the consumer market would take at least $20-25$ years. This prediction takes in account two parameters. First, the time to produce, breed and field-test a GM coffee for agronomic and biosafety purposes would take at least 15 years. Second, further time would be necessary for farmers to substitute actual cultivars with the new GM cultivars. Since the substitution of new coffee trees is a slow process, farm scale production of a significant amount of GM coffee would take another 10 years. The adoption rate of GM coffee by the farmers will also depend on the importance and value of the new characteristic introduced as well as the cost of this new technology to the farmer. The cost of royalties and/or technology fees may be intimidating, so the value and profitability of any new characteristic must be made clear to the farmer so as to ensure that he adopts this new technology quickly.

On the other hand, the delay in commercial introduction of genetic modified coffee might be advantageous. With the continuous use of GM crops around the globe (James, 2005) market and consumer perception on GM plants and food in the next 20 years might be more positive than it is today, easing the entry of GM coffee in farming systems. Consumer receptiveness would be facilitated if the initial GM products on the market also have significant characteristics for consumers, such as improvements in quality and health aspects, and not just advantages for the farmers.

\section{Conclusion and Perspectives}

In spite of possible market restrictions, genetic transformation of coffee will gradually become an important component in most coffee breeding programs in the medium and long term. The recent initiatives with coffee genomes (Lin et al. 2005; Vieira et al., in this publication) will undoubtedly bring a considerable amount of information and tools to be used in coffee genetics. Coffee plant transformation can be used to validate gene functions through over-expression or gene knock-out, providing insights into several areas of coffee plant research. The identification and characterization of specific and/or inducible coffee promoters (Marraccini et al., 2003; Satyanarayana et al., 2005) will allow a more refined regulation of the gene, leading to the use of this technology with greater precision. The continuous progress in monitoring the utilization of other GM crops around the world (Bates et al., 2005) will also help us to use the genetic transformation technology at the recommended biosafety levels.

\section{REFERENCES}

Barton CR, Adams TL, Zarowitz MA (1991) Stable Transformation of Foreign DNA into Coffea arabica Plants. In: Proceedings of the $14^{\text {th }}$ ASIC Colloquium. San Francisco, USA, pp.460-464.

Bates SL, Zhao JZ, Roush RT, Shelton AM (2005) Insect resistance management in GM crops: past, present and future. Nature Biotech. 23:57-62.

Blanco HG, Oliveira DA, Pupo EIH (1982), Período de competição de uma comunidade natural de mato em uma cultura de café, em formação. Biológico 48:9-20.

Berthouly M, Michaux-Ferriere NM (1996) High frequency somatic embryogenesis in Coffea canephora Induction conditions and histological evolution. Plant Cell Tissue Organ Cult. 44:169 - 176. 
Botterman J, Leemans J (1988), Engineering herbicide resistance in plants. Trends Genet. 4: 219-221.

Budzinski IGF, Cação SMB, Oliveira CA, Pereira LFP, Vieira LGE. (2005) Análise de genes expressos durante estádios finais da maturação de frutos de café. In: Anais do IV Simpósio de Pesquisa dos Cafés do Brasil, CD-ROM, Londrina, Paraná, Brazil.

Canche-Moo RLR, Ku-Gonzalez A, Burgeff C, LoyolaVargas VM, L.C. Rodríguez-Zapata LC, Castaño E (2006) Genetic transformation of Coffea canephora by vacuum infiltration. Plant Cell Tissue Organ Cult. DOI: 10.1007/ s11240-005-9036-4

Carneiro MF (1999) Advances in coffee biotechnology. AgBiotechNet 1:1-7.

Carvalho F (1982) O controle das plantas daninhas. Correio Agrícola 1:369-371.

Cruz ARR, Paixão ALD, Machado FR, Barbosa MFF, Junqueira CS, Cabral GB, Teixeira JB, Kobayashi AK, Brasileiro ACM, Barros EVSA (2004) Metodologia para obtenção de plantas transformadas de Coffea canephora por co-cultivo de calos embriogênicos com A. tumefaciens. Boletim de Pesquisa e Desenvolvimento 58. Embrapa, Brasília $15 \mathrm{p}$.

Cunha WG, Machado FRB, Vianna GR, Teixeira JB, Barros EVSA (2004) Obtenção de Coffea arábica geneticamente modificadas por bombardeamento de calos embriogênicos. Boletim de Pesquisa e desenvolvimento 73. Embrapa, Brasília $15 \mathrm{p}$.

Da Silva RF, Yuffá AM (2003) Transient gene expression in secondary somatic embryos from coffee tissues electroporated with the genes GUS and BAR. Eletronic J. Biotech. 6:29-35.

David K (2002) Fun without the buzz: decaffeination process and issues. http: //www.virtualcoffee.com/sept_2002/ decafe.html (Accessed Dec. 2005).

De La Riva GA, Gonzalez-Cabrera J, Vazquez-Padron R, AyraPardo C (1998) Agrobacterium tumefaciens: a natural tool for plant transformation. Electron. J. Biotech. 1:24-25.

Gray DJ, Finer JJ (1993) Development and operation of five particle guns for introduction of DNA into plant cells. Plant Cell Tissue Organ Cult 33:219.

Grossi de Sa MF, Pereira RA, Barros EVSA, Valencia A, Batista J, Oliveira Neto OB, Silva MCM, Bercot M, Figueira LZ (2004) O uso de inibidores de alfa-amilases no controle da broca-do-café.. In: Anais do Workshop Internacional de Manejo da Broca-do-Café, 2004, Londrina- Paraná.

Guerreiro Filho O, Denolf P, Peferoen M, Eskes AB, Frutos R (1998) Susceptibility of the Coffee Leaf Miner (Perileucoptera spp.) to Bacillus thuringiensis DeltaEndotoxins: a model for transgenic perennial crops resistant to endocarpic insects. Current Microbiol. 36:175-179.

Hatanaka J, Arakawa O, Yasuda T, Ushida N, Yamaguchi I (1991) Effect of plant growth regulators on somatic embryogenesis in leaf cultures of Coffea canephora. Plant Cell Rep. 10:179-182.
Hatanaka T, Choi YE, Kusano T, Sano H (1999) Transgenic plants of Coffea canephora from embryogenic callus via Agrobacterium tumefaciens-mediated transformation. Plant Cell Rep. 19:106-110.

Heilmann W (2001) Technology II: Decaffeination of Coffee. In: Clarke RJ and Vitzthum OG(eds)Coffee RecentDevelopments, Blackwee Sciences, Oxford, UK pp.108-124.

James C (2005). Executive Summary of Global Status of Commercialized Biotech/GM Crops: 2005. ISAAA Briefs No. 34. ISAAA: Ithaca, NY.

Kasuga M, Liu Q, Miura S, Shinozaki KY, Shinozaki K (1999) Improving plant drought, salt, and freezing tolerance by gene transfer of a single stress-inducible transcription factor. Nature Biotech. 17: 287-291.

Leroy T, Royer M, Paillard M, Berthouly M, Spiral J, Tessereau S, Legavre T, Altosaar I (1997) Introduction de genes d'intérêt agronomique dans l'espèce coffea canephora Pierre par transformation avec Agrobacterium sp. In: Proceedings of the $17^{\text {th }}$ ASIC Colloquium. Nairobi, Kenya, pp.439-446.

Leroy T, Dufour M (2004) Coffea spp. Genetic transformation. In: Curtis IS (ed), Transgenic Crops of the World: Essential Protocols. Kluwer Academic Publishers, Dordrecht, The Netherlands, pp.159-170.

Leroy T, Henry AM, Royer M, Altosar I, Frutos R, Duris D, Philippe R (2000) Genetically modified coffee plants expressing the Bacillus thuringiensis cry 1 Ac gene for resistance to leaf miner. Plant Cell Rep. 19:382-389.

Lin C, Mueller LA, McCarthy J, Crouzillat D, Pétiard V, Tanksley SD (2005) Coffee and tomato share common gene repertoires as revealed by deep sequencing of seed and cherry transcripts. Theor. Appl. Genet. 5:1-17.

Marraccini P, Courjault C, Caillet V, Lausanne F, Lepage B, Rogers WJ, Tessereau S, Deshayes A (2003) Rubisco small subunit of Coffea arabica: cDNA sequence, gene cloning and promoter analysis in transgenic tobacco plants Plant Physiol. Biochem. 41:17-25.

Mendez-Lopez I, Basurto-Rios R, Ibarra JE (2003) Bacillus thuringiensis serovar israelensis is highly toxic to the coffee berry borer, Hypothenemus hampei !Ferr. Coleoptera : Scolytidae) Fems Microbiol. Lett. 226:73-77.

Mishra MK, Sreenath HL (2004) High - Efficiency Agrobacterium - Mediated Transformation of Coffee (Coffee canephora Pierre ex. Frohner) using hypocotyls explants. In: Proceedings of the $19^{\text {th }}$ ASIC Colloquium. Bangalore, India, pp.792-796.

Mizuno K, Okuda A, Kato M, Yoneyama N, Tanaka H, Ashihara H, Fujimura T (2003) Isolation of a new dualfunctional caffeine synthase gene encoding an enzyme for the conversion of 7-methylxanthine to caffeine from coffee (Coffea arabica L.). FEBS Lett 534:75-81.

Molina DM, Aponte ME, Cortina H, Moreno G (2002) The effect of genotype and explant age on somatic embryogenesis of coffee. Plant Cell Tissue Organ Cult. 71:117-123. 
Molinari HCB, MARUR CJ, Bepalhok-Filho JC, Kobayashi AK, Pileggi M, Leite Júnior RP, Pereira LFP, Vieira LGE (2005) Osmotic adjustment in transgenic citrus rootstock Carrizo citrange (Citrus sinensis OSB. X Poncirus trifoliate L. Raf.) overproducing proline. Plant Sci. 167: 1375-1381.

Montagnon C (2005) Genetically modified coffees - the experience of CIRAD. Presentation in: ICO Seminar on Genetically Modified Coffee Workshop. http://www.ico.org/ event_pdfs/gm/gm.htm (Accessed Nov 2005).

Munkvold GP, Hellmich RL, Rice LG. (1999) Comparison of Fumosin Concentrations in Kernels of Transgenic Bt Maiza Hybrids and Nontransgenic Hybrids. Plant Disease 83:130-138.

Murashige T, Skoog F (1962) A revised medium for rapid growth and bio-assays with tobacco tissue culture. Plant Physiol. 15: 473-497.

Neupane KR, Moisyadi S, Stiles J (1999) Cloning and characterization of fruit-expressed ACC synthase and ACC oxidase from coffee. In: Proceedings of the $18^{\text {th }}$ ASIC Colloquium. Helsinki, Finland, pp.322-326.

Ocampo CA, Manzanera LM (1991) Advances in genetic manipulation of the coffee plant. In: Proceedings of $14^{\text {th }}$ ASIC Colloquim. San Francisco, USA, pp.378-382.

Ogawa M, Herai Y, Koizumi K, Kusano T, Sano H (2001) 7methylxanthine Methyltransferase of coffee plants. J. Biol. Chem. 276(11): 8213-8218.

Ogita S, Uefuji H, Yamaguchi Y, Koizumi N, Sano H (2003) Producing decaffeinated coffee plants. Nature 423:823.

Ogita S, Uefuji H, Morimoto M, Sano H (2004) Application of RNAi to confirm theobromine as the major intermediate for caffeine biosynthesis in coffee plants with potential for construction of decaffeinated varieties. Plant Mol. Biol. 54:931-941.

Ogita S, Uefuji H, Morimoto M, Sano H (2005) Metabolic engineering of caffeine production. Plant Biotechnol. 22: 461-468.

Parcy F (2005) Flowering: a time for integration. Int. J. Dev. Biol. 49: 585-593.

Penna S, Sagi L, Swennen R (2002) Positive selectable marker genes for routine plant transformation. In Vitro Cel. Develop. Biol-Plant 38:125-128.

Pereira, LFP, Galvão, RM, Kobayashi AK, Cação, SMB, Vieira LGE. (2005) Ethylene production and ACC oxidase gene expression during fruit ripening of Coffea arabica L. Braz. J. Plant Physiol. 17:283-289.

Pérez J, Infante F, Vega FE, Holguín F, Holguin J, Macias J, Valle J, Nieto G, Peterson SW, Kurtzman CP (2003) Mycobiota associated with the coffee berry borer (Hypothenemus hampei) in Mexico. Mycological Res. 107: 879-887.

Perthuis B, Pradon J, Montagnon C, Dufour M, Leroy T (2005) Stable resistance against the leaf miner Leucoptera coffeella expressed by genetically transformed Coffea canephora in a pluriannual field experiment in French Guiana. Euphytica 144:321-329.

Ribas AF, Kobayashi AK, Galvão RM, Bespalhok Filho JC, Pereira LFP, Vieira LGE (2001) Transformação de Coffea canephora $\mathrm{P}$. com gene para resistência ao glufosinato de amônio usando bombardeamento de partículas. In: Anais do II Simpósio de Pesquisa sobre os Cafés do Brasil. Vitória, Espírito Santo, pp.34.

Ribas AF, Kobayashi AK, Cação SMB, Pereira LFP, Ayub RA, Vieira LGE (2003) Transformação genética de Coffea canephora P. mediada por Agrobacterium tumefaciens com gene heterólogo de ACC-Oxidase na orientação anti-senso. In: Anais do III Simpósio de Pesquisa dos Cafés do Brasil. Porto Seguro, Bahia, Brazil, pp.106-107.

Ribas AF, Kobayashi AK, Pereira LFP, Vieira LGE (2005a) Genetic transformation of Coffea canephora P. by particle bombardment. Biol. Plant. 49:493-497.

Ribas AF, Galvão, RM, Pereira LFP, Vieira LGE (2005b) Transformação de Coffea arabica com o gene da ACCoxidase em orientação antisenso. $51^{\circ}$ Congresso Brasileiro de Genética. Águas de Lindóia, São Paulo, Brazil, pp.492.

Ribas AF, Kobayashi AK, Pereira LFP, Vieira LGE (2006) Production of herbicide-resistant coffee plants (Coffea canephora P.) via Agrobacterium tumefaciens-mediated transformation. Braz. Arc. Biol. Technol. 49:11-19.

Rosillo AG, Acuna JR, Gaitan AL, Pena M (2003) Optimized DNA delivery into Coffea arabica suspension culture cells by particle bombardment. Plant Cell Tissue Organ Cult. 74: 45-49.

Samson NP, Campa C, Noirot M, Kochko A. (2004) Potential use of D-xylose for coffee plant transformation. In: Proceedings of the $19^{\text {th }}$ ASIC Colloquium. Bangalore, Índia.pp.707-713.

Satyanarayana KV, Kumar V, Chandrashekar A, Ravishankar GA (2005).Isolation of promoter for N-methyltransferase gene associated with caffeine biosynthesis in Coffea canephora. J. Biotechnol. 119:20-25.

Silvarolla MB, Mazzafera P, Fazuoli LC (2004) A naturally decaffeinated arabica coffee. Nature 429:826.

Spiral J, Leroy T, Paillard M, Petiard V (1999) Transgenic coffee (Coffea sp.). In: Bajaj YPS (ed), Biotechnology in Agriculture and Forestry. Transgenic Trees, pp.55-76. Spring-Verlag, Berlim, Heidelberg.

Spiral J, Petiard V (1991) Protoplast culture and regeneration in coffee species. In: Proceedings of the 14th ASIC Colloquium, San Francisco, USA, pp.383-391.

Spiral J, Thierry C, Paillard M, Petiard V (1993) Obtention de plantules de Coffea canephora Pierre (Robusta) transformées par Agrobacterium rhizogenes. Compt. Rend. Acad. Sci. Paris 316:1-6.

Stiles; J; Moisyadi I; Neupane K R (2000) Purified proteins, recombinant DNA sequences and processes for producing caffeine free beverages. USA Patent 6,075,184. 
Sugiyama M., Matsuoka C, Takagi T (1995) Transformation of Coffea with Agrobacterium rhizogenes. In: Proceedings of the 16th ASIC Colloquium, Kyoto, Japan, pp.853-859.

Uefuji H, Ogita S, Yamaguchi Y, Koizumi N, Sano H (2003a) Molecular Cloning and Functional Characterization of Three Distinct N-Methyltransferases Involved in the Caffeine Biosynthetic Pathway in Coffee Plants. Plant Physiol. 132:372-380.

Uefuji H, Koizumi N, Sano H, Shinmyo A (2003b) Caffeine synthase and use thereof. Patent WO 2003/087376 A1.
Van Boxtel J, Eskes A, Berthouly M (1995) Glufosinate as an efficient inhibitor of callus proliferation in coffee tissue. In Vitro Cell. Dev. Biol. - Plant 33: 6-12.

Van Boxtel J, Berthouly M, Carasco C, Dufuor M, Eskes A (1995) Transient expression of $\beta$-glucoronidase following biolistic delivery of foreign DNA into coffee tissue. Plant Cell Rep. 14:748-752.

Vinecky F, Brito KM, Da Silva FR, Andrade AC (2005) Análise in silico de genes potencialmente envolvidos na resposta aos estresses abióticos, presentes na base de dados do genoma café. In: Anais do IV Simpósio de Pesquisa dos Cafés do Brasil, Londrina, Paraná, Brazil, CD-ROM. 